\author{
Synthesis of Cladobotryal, CJ16,169, and CJ16,170 \\ Barry B. Snider* and Qinglin Che \\ Department of Chemistry MS 015, Brandeis University, Waltham, MA 02454-9110 \\ snider@brandeis.edu
}

Supporting Material

Experimental Procedures

S2

Table of Spectral Data for 2, 3, 25 and 26

S14

Copies of ${ }^{1} \mathrm{H}$ and ${ }^{13} \mathrm{C}$ NMR spectra

S15-S53 
General procedures. NMR spectra were recorded at $400 \mathrm{MHz}$ in $\mathrm{CDCl}_{3}$ unless otherwise indicated. Chemical shifts are reported in $\delta$ and coupling constants in Hz. Chemical shifts are referenced to $\mathrm{CDCl}_{3}$ at $\delta 77.00\left({ }^{13} \mathrm{C}\right)$ and residual $\mathrm{CHCl}_{3}$ at $7.27\left({ }^{1} \mathrm{H}\right)$. NMR spectra recorded in acetone- $d_{6}$ are referenced to $\delta 30.3\left({ }^{13} \mathrm{C}\right)$ and $\delta 2.00\left({ }^{1} \mathrm{H}\right)$ to be consistent with the reported values for compounds $\mathbf{1}, \mathbf{2}$ and $3{ }^{2}$ IR spectra are reported in $\mathrm{cm}^{-1}$.

Ethyl 3-(4-chlorophenylsulfanyl)-2-(4-hydroxy-2-oxo-5-phenyl-1,2-dihydropyridine-3-yl)-propionate (16) and ethyl 2-(4-hydroxy-2-oxo-5-phenyl-1,2-dihydropyridin-3-yl)-propionate (17). To a stirred solution of pyridone 7 (880 $\mathrm{mg}, 5 \mathrm{mmol})$ in $20 \mathrm{~mL}$ of anhydrous EtOH in a resealable pressure reaction tube was added ethyl pyruvate (2.32 g, 2.21 $\mathrm{mL}, 20 \mathrm{mmol})$ and $p$-chlorothiophenol $(2.90 \mathrm{~g}, 20 \mathrm{mmol})$. To the solution were then added 0.2 $\mathrm{mL}$ of $\mathrm{NEt}_{3}$ and $0.2 \mathrm{~mL}$ of HOAc. The reaction tube was sealed under $\mathrm{N}_{2}$, immersed in a $110^{\circ} \mathrm{C}$ oil bath, and stirred for $3 \mathrm{~d}$. Evaporation of the solvent under reduced pressure gave a yellow oil that was dissolved in $100 \mathrm{~mL}$ of EtOAc. The resulting solution was washed with 0.1 $\mathrm{M} \mathrm{HCl}$, saturated $\mathrm{NaHCO}_{3}$ and brine, dried over $\mathrm{Na}_{2} \mathrm{SO}_{4}$, and concentrated under reduced pressure. Flash chromatography of the residue on silica gel $\left(100: 1 \sim 50: 1 \mathrm{CH}_{2} \mathrm{Cl}_{2} / \mathrm{MeOH}\right)$ gave $255 \mathrm{mg}(12 \%)$ of thioether $\mathbf{1 6}$ as a white solid, followed by $1.01 \mathrm{~g}(72 \%)$ of ethyl ester $\mathbf{1 7}$ as a white solid.

To a solution of $\mathbf{1 6}(107 \mathrm{mg}, 0.25 \mathrm{mmol})$ in $5 \mathrm{~mL}$ of 9:1 acetone/EtOH was added $0.75 \mathrm{~g}$ of a $50 \%$ slurry of Raney nickel in water (Aldrich). The mixture was vigorously stirred at $25^{\circ} \mathrm{C}$ for $12 \mathrm{~h}$. The mixture was diluted with $20 \mathrm{~mL}$ of $\mathrm{CH}_{2} \mathrm{Cl}_{2}$ and the nickel was removed cautiously by filtration through Celite. The filtrate was dried over $\mathrm{Na}_{2} \mathrm{SO}_{4}$ and concentrated under reduced pressure. Flash chromatography on silica gel $\left(50: 1 \mathrm{CH}_{2} \mathrm{Cl}_{2} / \mathrm{MeOH}\right)$ gave $68 \mathrm{mg}$ (95\%) of ethyl ester $\mathbf{1 7}$ as a white solid. The combined yield of ethyl ester $\mathbf{1 7}$ from pyridone $\mathbf{7}$ (from 7 to $\mathbf{1 7}$ and from 7 to $\mathbf{1 6}$ to $\mathbf{1 7}$ ) is $83 \%$.

Data for 16: $\quad \mathrm{mp} 76-77{ }^{\circ} \mathrm{C} ;{ }^{1} \mathrm{H}$ NMR 7.46-7.20 (m, 10), $4.66(\mathrm{dd}, 1, J=9.2,6.7), 4.31-4.16$ (m, 2,), 3.56 (dd, $1, J=13.4,9.2), 3.34$ (dd, $1, J=13.4,6.7), 1.29$ (t, $3, J=7.3) ;{ }^{13} \mathrm{C}$ NMR 176.2, 
164.6, 163.3, 134.0, 133.3, 132.2, 131.0 (2 C), 129.1 (2 C), 128.8 (2 C), 128.7, 128.6 (2 C), 127.7, 115.8, 107.4, 62.3, 41.6, 34.3, 14.0; IR (neat) 1726, 1647.

Data for 17: $\quad \mathrm{mp} \mathrm{81-82}{ }^{\circ} \mathrm{C} ;{ }^{1} \mathrm{H}$ NMR 7.45-7.30 (m, 6), 4.53 (q, $\left.1, J=7.3\right), 4.30-4.16(\mathrm{~m}, 2)$, $1.50(\mathrm{~d}, 3, J=7.3), 1.30(\mathrm{t}, 3, J=7.3) ;{ }^{13} \mathrm{C}$ NMR 179.1, 164.8, 163.2, 133.7, 132.7, 129.2 (2 C), 128.5 (2 C), 127.6, 116.3, 109.9, 62.1, 35.7, 16.0, 13.9; IR (neat) 1728, 1644.

3-Methyl-7-phenyl-3,5-dihydro-furo[3,2-c] pyridine-2,4-dione (6). To a solution of $\mathbf{1 7}$ (861 mg, $3 \mathrm{mmol}$ ) in $50 \mathrm{~mL}$ of anhydrous toluene was added $1 \mathrm{~mL}$ of TFA. The solution was reflux at $110^{\circ} \mathrm{C}$ for $12 \mathrm{~h}$, at which time TLC $\left(1: 20 \mathrm{MeOH} / \mathrm{CH}_{2} \mathrm{Cl}_{2}\right)$ showed that no 17 was left. After cooling to $25^{\circ} \mathrm{C}$, the mixture was concentrated to $\sim 10 \mathrm{~mL}$ and left in a refrigerator overnight to crystallize 6. The solution was filtered and the precipitate was washed with cold $\mathrm{Et}_{2} \mathrm{O}$ and EtOAc and dried at $100{ }^{\circ} \mathrm{C}$ for $2 \mathrm{~h}$ to give $670 \mathrm{mg}(93 \%)$ of lactone 6 as a white solid: $\mathrm{mp} 267{ }^{\circ} \mathrm{C}(t-\mathrm{BuOH}) ;{ }^{1} \mathrm{H}$ NMR (DMSO- $\left.d_{6}\right) 7.70(\mathrm{~s}, 1), 7.54-7.32(\mathrm{~m}, 5), 3.91$ (q, $1, J=7.3$ ), $1.46(\mathrm{~d}, 3, J=7.3) ;{ }^{13} \mathrm{C}$ NMR (DMSO- $\left.d_{6}\right) 177.1,159.5,158.6,135.7,132.1,128.7$ (2 C), 127.5 (2 C), 127.4, 112.5, 107.9, 36.5, 13.4; IR (neat) 1817, 1668; HRMS (CI) calcd for $\mathrm{C}_{14} \mathrm{H}_{12} \mathrm{NO}_{3}$ $\left(\mathrm{MH}^{+}\right)$241.0739, found 241.0732.

Alternatively, 17 (29 mg, $0.1 \mathrm{mmol}$ ) was put into a small sublimation apparatus that was heated at $190{ }^{\circ} \mathrm{C}$ at 2 torr for $20 \mathrm{~min}$. The white sublimate was collected to give $22 \mathrm{mg}(91 \%)$ of lactone 6 .

\section{2-(4-Hydroxy-2-oxo-5-phenyl-1,2-dihydropyridin-3-yl)-propionic acid.}

Triethylammonium formate (TEAF) reagent with the composition of $\left(\mathrm{Et}_{3} \mathrm{~N}\right)_{2} \cdot\left(\mathrm{HCO}_{2} \mathrm{H}\right)_{5}$ was freshly prepared by mixing $\mathrm{Et}_{3} \mathrm{~N}(6.72 \mathrm{~mL}, 48 \mathrm{mmol})$ with $\mathrm{HCO}_{2} \mathrm{H}(5.52 \mathrm{~g}, 4.53 \mathrm{~mL}, 120 \mathrm{mmol})$ at $0{ }^{\circ} \mathrm{C}$. To a stirred solution of $7(132 \mathrm{mg}, 0.75 \mathrm{mmol})$ in $2 \mathrm{~mL}$ of TEAF in a resealable pressure reaction tube was added dropwise ethyl pyruvate $(120 \mu \mathrm{L}, 1.5 \mathrm{mmol})$. The solution was sealed under $\mathrm{N}_{2}$ and stirred at $140-150{ }^{\circ} \mathrm{C}$ for $5 \mathrm{~h}$. The reaction mixture was cooled and poured into $10 \mathrm{~mL}$ of cold water, the mixture was acidified with $6 \mathrm{M} \mathrm{HCl}$ to $\mathrm{pH} 2$, saturated with $\mathrm{NaCl}$ and extracted with EtOAc. The organic phase was dried over $\mathrm{Na}_{2} \mathrm{SO}_{4}$ and concentrated under reduced pressure. Flash chromatography of the residue on silica gel (4:1 EtOAc/EtOH) 
gave $72 \mathrm{mg}(40 \%)$ of the propionic acid as a white solid: $\mathrm{mp} 155-156{ }^{\circ} \mathrm{C} ;{ }^{1} \mathrm{H} \mathrm{NMR}$ (acetone- $\left.d_{6}\right) 7.43-7.24(\mathrm{~m}, 6), 4.27(\mathrm{q}, 1, J=7.1), 1.42(\mathrm{~d}, 3, J=7.1) ;{ }^{13} \mathrm{C}$ NMR (acetone- $\left.d_{6}\right)$ 178.3, 164.5, 163.7, 134.7, 133.9, 130.4 (2 C), 129.4 (2 C), 128.6, 117.4, 112.3, 36.9, 15.9; IR (KBr), 1700, 1649, 1429, 1217.

The acid was converted to ester $\mathbf{1 7}$ by the following procedure. A solution of the acid (25.9 $\mathrm{mg}, 0.1 \mathrm{mmol}$ ) in $1 \mathrm{~mL}$ of anhydrous EtOH was treated with 3 drops of $98 \% \mathrm{H}_{2} \mathrm{SO}_{4}$ and the solution was stirred at $60^{\circ} \mathrm{C}$ for $4 \mathrm{~h}$. The solvent was evaporated and the residue was redissolved in $10 \mathrm{~mL}$ of $\mathrm{CH}_{2} \mathrm{Cl}_{2}$. The solution was washed with saturated $\mathrm{NaHCO}_{3}$ and brine, dried over $\mathrm{Na}_{2} \mathrm{SO}_{4}$, and concentrated under reduced pressure. Flash chromatography on silica gel (4:1 EtOAc/hexanes) gave $28 \mathrm{mg}(98 \%)$ of 17 as a white solid.

The acid was converted to 6 by following procedure. The acid $(25.9 \mathrm{mg}, 0.1 \mathrm{mmol})$ was put into a small sublimation apparatus, which was heated at $220{ }^{\circ} \mathrm{C}$ at 2 torr for $20 \mathrm{~min}$. The apparatus was cooled and the white sublimate was collected to give $22 \mathrm{mg}$ (91\%) of lactone 6 as a white solid.

\section{2,4-Bis-(t-butyldimethylsilanyloxy)-3-methyl-7-phenylfuro[3,2-c]pyridine (18) and} 4-(t-Butyldimethylsilanyloxy)-3-methyl-7-phenyl-3H-furo[3,2-c]pyridin-2-one (20). $t$-Butyldimethylsilyl trifluromethanesulfate $(460 \mu \mathrm{L}, 2 \mathrm{mmol})$ was added dropwise to a stirring slurry of lactone $6(241 \mathrm{mg}, 1 \mathrm{mmol})$ and $\mathrm{Et}_{3} \mathrm{~N}(332 \mu \mathrm{L}, 2.4 \mathrm{mmol})$ in $5 \mathrm{~mL}$ of anhydrous $\mathrm{CH}_{2} \mathrm{Cl}_{2}$ under $\mathrm{N}_{2}$ at $0{ }^{\circ} \mathrm{C}$. The reaction was allowed to stir at $0{ }^{\circ} \mathrm{C}$ for $1 \mathrm{~h}$ at which time a clear solution had formed. The reaction mixture was diluted with $20 \mathrm{~mL}$ of $\mathrm{CH}_{2} \mathrm{Cl}_{2}$, washed with ice-cold water $(2 \times 5 \mathrm{~mL})$, dried over $\mathrm{Na}_{2} \mathrm{SO}_{4}$ and concentrated under reduced pressure to give crude furopyridine $\mathbf{1 8}$ as a colorless oil, which was unstable under acidic or basic conditions and readily decomposed on silica gel. Spectral data was obtained from crude 18: ${ }^{1}$ H NMR 7.98 (s, 1), $7.74(\mathrm{~d}, 2, J=7.6), 7.45(\mathrm{dd}, 2, J=7.6,7.6), 7.34(\mathrm{t}, 1, J=7.6), 2.18(\mathrm{~s}, 3), 1.04(\mathrm{~s}, 9)$, $1.00(\mathrm{~s}, 9), 0.42$ (s, 6), 0.29 (s, 6); ${ }^{13} \mathrm{C}$ NMR 155.9, 154.3, 151.7, 137.7, 134.2, 128.5 (2 C), 127.7 (2 C), 127.1, 125.1, 115.6, 89.1, 25.8 (3 C), 25.3 (3 C), 18.0, 17.9, 8.0, -4.2 (2 C), -4.5 (2 C); IR (neat) $1661,1470,1254,1076$. 
To a solution of crude 18 in $10 \mathrm{~mL}$ of $\mathrm{CH}_{2} \mathrm{Cl}_{2}$ was added $0.5 \mathrm{~mL}$ of $\mathrm{NEt}_{3}$ and $1 \mathrm{~mL}$ of water. The resulting mixture was stirred at $25^{\circ} \mathrm{C}$ for 20 min and diluted with $10 \mathrm{~mL}$ of $\mathrm{CH}_{2} \mathrm{Cl}_{2}$. The organic phase was washed with brine extensively $(5 \times 5 \mathrm{~mL})$, dried over $\mathrm{Na}_{2} \mathrm{SO}_{4}$ and quickly passed through a short pad of silica gel. The solution was concentrated and then kept under vacuum ( 2 torr) overnight at $25{ }^{\circ} \mathrm{C}$ to give $324 \mathrm{mg}$ (91\%) of furopyridine $\mathbf{2 0}$ as a colorless oil: ${ }^{1}$ H NMR. 8.23 (s, 1), 7.60 (d, 2, $J=7.6$ ), 7.45 (dd, 2, $J=7.6,7.6$ ), 7.36 (t, $1, J=7.6$ ), 3.79 (q, 1, $J=7.3), 1.65$ (d, 3, $J=7.3$ ), 1.02 (s, 9), 0.41 (s, 3), 0.38 (s, 3); ${ }^{13} \mathrm{C}$ NMR 176.7, 159.2, 158.1, 147.1, 132.8, 128.8 (2 C), 128.0 (2 C), 127.8, 115.9, 110.6, 36.3, 25.8 (3 C), 17.9, 14.5, -4.1, -4.3; IR (neat) 1819, 1463.

Alternatively, when 5 equivalent of $\mathrm{NEt}_{3}$ was used in the protection step, washing the crude reaction mixture with brine $(8 \times 5 \mathrm{~mL})$ directly gave furopyridinone $\mathbf{2 0}$ in $87 \%$ yield after similar workup. Attempted purification of $\mathbf{2 0}$ by flash chromatography was unsuccessful due to its partial deprotection on silica gel.

\section{2-(t-Butyldimethylsilanyloxy)-3-methyl-7-phenyl-5H-furo[3,2-c]pyridin-4-one (19).} $t$-Butyldimethylsilyl trifluromethanesulfate ( $46 \mu \mathrm{L}, 0.2 \mathrm{mmol}$ ) was added dropwise to a slurry of lactone $6(24.1 \mathrm{mg}, 0.1 \mathrm{mmol})$ and $\mathrm{Et}_{3} \mathrm{~N}(29.1 \mu \mathrm{L}, 0.21 \mathrm{mmol})$ in $0.5 \mathrm{~mL}$ of anhydrous $\mathrm{CH}_{2} \mathrm{Cl}_{2}$ under $\mathrm{N}_{2}$ at $0{ }^{\circ} \mathrm{C}$. The reaction was stirred at $0{ }^{\circ} \mathrm{C}$ for $1 \mathrm{~h}$ at which time a clear solution was formed. The reaction mixture was diluted with $4 \mathrm{~mL}$ of $\mathrm{CH}_{2} \mathrm{Cl}_{2}$, washed with brine, dried over $\mathrm{Na}_{2} \mathrm{SO}_{4}$ and concentrated under reduced pressure to give crude $\mathbf{1 8}$ as a colorless oil. Flash chromatography on silica gel $\left(\mathrm{CH}_{2} \mathrm{Cl}_{2}\right.$ then EtOAc) gave $28.6 \mathrm{mg}$ (81\%) of monoprotected furopyridinone 19 as a colorless oil: ${ }^{1} \mathrm{H}$ NMR 7.64 (d, 2, $\left.J=7.9\right), 7.40$ (dd, 2, $J=7.9,7.3$ ), $7.35(\mathrm{t}, 1, J=7.3), 7.26(\mathrm{~s}, 1), 2.27$ (s, 3), 1.01 (s, 9), $0.28(\mathrm{~s}, 6) ;{ }^{13} \mathrm{C}$ NMR 161.9, 154.0, 150.3, 132.9, 128.6 (2 C), 127.4 (2 C), 127.3, 126.1, 117.5, 111.1, 90.7, 25.4 (3 C), 18.1, 7.4, -4.5 (2 C); IR (neat) 2931, 1644, 1406, 1230.

2-Methyl-2-butenoyl chloride (Tigloyl chloride). Tiglic acid (2.0 g, $20 \mathrm{mmol}$ ) was dissolved in $2.5 \mathrm{~mL}$ of oxalyl dichloride at $25{ }^{\circ} \mathrm{C}$. The solution was stirred under nitrogen for $12 \mathrm{~h}$. Excess oxalyl dichloride was removed under reduced pressure. The residue was filtered 
through a short Celite pad to give $2.30 \mathrm{~g}$ (99\%) of 2-methyl-2-butenoyl chloride (tigloyl chloride) as a colorless liquid: ${ }^{1} \mathrm{H}$ NMR 7.3 (qq, 1, $J=7.3,1.2$ ), 1.94 (d, 3, $J=7.3$ ), 1.91 (br s, 3); ${ }^{13}$ C NMR 168.9, 147.7, 133.5, 15.3, 13.0; IR (neat) 1751, 1644, 1213.

4-(t-Butyldimethylsilanyloxy)-3-methyl-3-(2-methyl-2-butenoyl)-7-phenyl-3H-furo[3,2clpyridin-2-one and 3-Methyl-3-(2-methyl-2-butenoyl)-7-phenyl-3,5-dihydrofuro[3,2-c]pyridine-2,4-dione (22). A $2.5 \mathrm{M}$ solution of $n$-BuLi in hexane (400 $\mu \mathrm{L}, 1.0 \mathrm{mmol})$ was diluted with $2.0 \mathrm{~mL}$ of anhydrous $\mathrm{THF}$ and the resulting solution was cooled to $-78^{\circ} \mathrm{C}$ under nitrogen. A solution of $\mathbf{2 0}(284 \mathrm{mg}, 0.8 \mathrm{mmol})$ in $5 \mathrm{~mL}$ of THF was then added dropwise via syringe over a period of $2 \mathrm{~min}$. The mixture was stirred at $-78{ }^{\circ} \mathrm{C}$ for $30 \mathrm{~min}$ and tigloyl chloride (118 mg, $1.0 \mathrm{mmol})$ was added dropwise with syringe. The mixture was stirred at $-78^{\circ} \mathrm{C}$ for $2 \mathrm{~h}$ and warmed to $0{ }^{\circ} \mathrm{C}$ over $30 \mathrm{~min}$. The mixture was quenched with $0.1 \mathrm{~mL}$ of water, concentrated under reduced pressure to remove most of the solvent, and diluted with 100 $\mathrm{mL}$ of $10 \%$ EtOAc in hexanes. The mixture was quickly filtered through a short column of silica gel and concentrated to give the crude TBSO-furopyridine as a white solid, which was immediately deprotected. For spectral characterization purpose, a small portion was purified by flash chromatography on deactivated silica gel (30:1 hexane/EtOAc) to give the TBSO-furopyridine as a white solid: $\quad{ }^{1} \mathrm{H}$ NMR 8.29 (s, 1), 7.65 (d, 2, $\left.J=7.9\right), 7.49$ (dd, 2, $J=$ 7.9, 7.3), 7.40 (t, 1, $J=7.3$ ), 6.05 (qq, $1, J=6.7,1.2), 1.76$ (s, 3), 1.74 (br s, 3), 1.66 (d, $3, J=$ 6.7), 0.95 (s, 9), 0.35 (s, 3), 0.30 (s, 3); ${ }^{13} \mathrm{C}$ NMR 191.0, 174.1, 158.2, 157.2, 147.8, 136.8, 136.1, 132.5, 128.9 (2 C), 128.1, 127.9 (2 C), 116.1, 113.9, 54.9, 25.5, (3 C), 21.2, 17.9, 14.7, 12.4, -4.3 (2 C).

The crude TBSO-furopyridine was dissolved in $10 \mathrm{~mL}$ of $\mathrm{CH}_{2} \mathrm{Cl}_{2}$ and the solution was treated with $1 \mathrm{~mL}$ of anhydrous $\mathrm{HOAc}$ at $0{ }^{\circ} \mathrm{C}$ and stirred at $25^{\circ} \mathrm{C}$ for 20 min at which time TLC (20:1 hexanes/EtOAc) showed that no starting material was left. The solution was diluted with $20 \mathrm{~mL}$ of $\mathrm{CH}_{2} \mathrm{Cl}_{2}$, washed with saturated $\mathrm{NaHCO}_{3}, 1 \mathrm{M} \mathrm{HCl}$ and brine, dried over $\mathrm{Na}_{2} \mathrm{SO}_{4}$, and concentrated under reduced pressure. Flash chromatography of the residue on silica gel (50:1 
$\mathrm{CH}_{2} \mathrm{Cl}_{2} / \mathrm{MeOH}$ ) gave $203 \mathrm{mg}$ (78\%) of keto lactone 22 as a white solid, followed by $19.5 \mathrm{mg}$ $(10 \%)$ of recovered lactone $\mathbf{6}$ as a white solid.

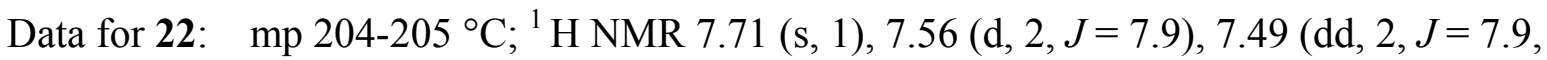
7.3), 7.42 (t, $1, J=7.3$ ), 6.21 (qq, $1, J=6.7,1.2), 1.81$ (s, 3), 1.80 (br s, 3), 1.73 (d, 3, $J=6.7$ ); ${ }^{13}$ C NMR 191.3, 173.7, 160.3, 159.8, 136.6, 136.4, 136.3, 131.2, 129.1 (2 C), 128.3, 127.6 (2 C), 116.0, 110.5, 55.7, 20.8, 14.8, 12.6; IR (KBr) 1820, 1664; HRMS (CI) calcd for $\mathrm{C}_{19} \mathrm{H}_{18} \mathrm{NO}_{4}$ $\left(\mathrm{MH}^{+}\right)$324.1236, found 324.1248.

4-Hydroxy-3-(2-hydroxy-1-methylethyl)-5-phenyl-1H-pyridin-2-one (24). To a stirred solution of lactone $6(48.2 \mathrm{mg}, 0.2 \mathrm{mmol})$ in $1 \mathrm{~mL}$ of THF at $0{ }^{\circ} \mathrm{C}$ was added dropwise a $1.0 \mathrm{M}$ solution of LAH in THF $(0.2 \mathrm{~mL}, 0.2 \mathrm{mmol})$ over a period of 5 min under $\mathrm{N}_{2}$. The solution was stirred at $0{ }^{\circ} \mathrm{C}$ for $1 \mathrm{~h}$, warmed to $25^{\circ} \mathrm{C}$, and stirred for another $24 \mathrm{~h}$. The reaction mixture was diluted with $10 \mathrm{~mL}$ of $\mathrm{CH}_{2} \mathrm{Cl}_{2}$ and quenched with $0.5 \mathrm{~mL}$ of saturated $\mathrm{NH}_{4} \mathrm{Cl}$. The white precipitate that formed was filtrated and washed with EtOAc. The combined organic phases were washed with saturated $\mathrm{NaHCO}_{3}$ and brine, dried over $\mathrm{Na}_{2} \mathrm{SO}_{4}$, and concentrated under reduced

pressure. Flash chromatography of the residue on silica gel $\left(25: 1 \mathrm{CH}_{2} \mathrm{Cl}_{2} / \mathrm{MeOH}\right)$ gave $46.5 \mathrm{mg}$ (96\%) of alcohol 24 as a white solid: $\mathrm{mp} 171-172{ }^{\circ} \mathrm{C} ;{ }^{1} \mathrm{H}$ NMR $\left(\mathrm{CD}_{3} \mathrm{OD}\right)$ 7.42-7.27 (m, 5), 7.17 (s, 1), 3.91 (dd, $1, J=10.4,4.0), 3.81$ (dd, $1, J=10.4,2.2), 3.67-3.60$ (m, 1), 1.28 (d, 3, $J=$ 7.3); ${ }^{13} \mathrm{C}$ NMR ( $\mathrm{CD}_{3} \mathrm{OD} /$ acetone- $\left.d_{6}\right)$ 165.7, 164.8, 136.2, 132.7, 130.4 (2 C), 129.1 (2 C), 128.1, 118.0, 116.1, 66.9, 32.8, 15.1; IR (KBr) 3250, 1643, 1416.

\section{4-Hydroxy-3-(2-hydroxy-1-hydroxymethyl-1,3-dimethylpent-3-enyl)-5-phenyl-1 $H$-pyri}

din-2-one (4a and 4b). To a vigorously stirred solution of keto lactone $22(165 \mathrm{mg}, 0.2 \mathrm{mmol})$ in $4 \mathrm{~mL}$ of THF at $-78{ }^{\circ} \mathrm{C}$ was added dropwise a $1.5 \mathrm{M}$ solution of DIBAL-H in toluene $(0.4 \mathrm{~mL}$, $0.6 \mathrm{mmol}$ ) over a period of $5 \mathrm{~min}$ under $\mathrm{N}_{2}$. The solution was stirred at $-78^{\circ} \mathrm{C}$ for $3 \mathrm{~h}$ and treated dropwise with a $1 \mathrm{M}$ solution of LAH in THF $(0.3 \mathrm{~mL}, 0.3 \mathrm{~mol})$. The reaction was warmed to $25^{\circ} \mathrm{C}$ over $2 \mathrm{~h}$ and stirring was continued for $16 \mathrm{~h}$. The reaction mixture was diluted with $15 \mathrm{~mL}$ of $\mathrm{CH}_{2} \mathrm{Cl}_{2}$ and quenched with $1 \mathrm{~mL}$ of saturated $\mathrm{NH}_{4} \mathrm{Cl}$. The reaction mixture was quickly treated with $10 \mathrm{~mL}$ of $1 \mathrm{M} \mathrm{HCl}$ to dissolve the aluminum salts and the 
aqueous phase was extracted with EtOAc $(2 \times 5 \mathrm{~mL})$. The combined organic phases were washed with saturated $\mathrm{NaHCO}_{3}$ and brine, dried over $\mathrm{Na}_{2} \mathrm{SO}_{4}$, and evaporated under reduced pressure to give $160 \mathrm{mg}$ of a white solid consisting of $75 \%$ of diols $\mathbf{4 a} / \mathbf{4 b}(1: 1), 15 \%$ of $\mathbf{2 4}$ and $10 \%$ of tiglic alcohol as determined from the ${ }^{1} \mathrm{H}$ NMR spectrum. Due to the instability of the diols on column chromatography, this crude product was cyclizated without further purification.

Flash chromatography on silica gel (99:1 to $\left.25: 1 \mathrm{CH}_{2} \mathrm{Cl}_{2} / \mathrm{MeOH}\right)$ of $160 \mathrm{mg}$ of crude reaction mixture gave $60 \mathrm{mg}$ of cyclization products containing $\mathbf{2 , 3}, \mathbf{2 5}$, and $\mathbf{2 6}$ and some unidentified compounds, followed by $32 \mathrm{mg}$ of $70 \%$ pure diol $\mathbf{4 a}, 35 \mathrm{mg}$ of $80 \%$ pure diol $\mathbf{4 b}$, and $17 \mathrm{mg}(14 \%)$ of $\mathbf{2 4}$ as a white solid.

Recrystalization of the $70 \%$ pure $4 \mathbf{a}$ from $\mathrm{CHCl}_{3}$ gave $20 \mathrm{mg}$ (12\% from 22 ) of $\mathbf{4 a}$ as a white solid: $\quad \mathrm{mp} 205-206{ }^{\circ} \mathrm{C} ;{ }^{1} \mathrm{H}$ NMR $\left(\mathrm{CD}_{3} \mathrm{OD}\right)$ 7.40-7.27 (m, 5), 7.21 (s, 1), 5.46 (q, $1, J=6.7$ ), 4.39 (d, $1, J=11.6$ ), 4.15 (s, 1), 3.37 (d, 1, $J=11.6$ ), 1.59 (d, 3, $J=6.7$ ), 1.50 (s, 3), 1.49 (br s, $3) ;{ }^{13} \mathrm{C}$ NMR ( $\left.\mathrm{CD}_{3} \mathrm{OD}\right)$ 168.4, 166.1, 36.9, 136.5, 133.4, 130.6 (2 C), 129.0 (2 C), 128.2, 125.0, 119.5, 115.1, 85.2, 70.1, (one carbon signal was obscured by $\mathrm{CD}_{3} \mathrm{OD}$ peaks), 21.2, 13.3, 12.0; IR (neat) $3235,1644,1405,1221$; HRMS (FAB) calcd for $\mathrm{C}_{19} \mathrm{H}_{24} \mathrm{NO}_{4}\left(\mathrm{MH}^{+}\right) 330.1705$, found 330.1695 .

Reverse phase chromatography on Bakerbond Octadecyl $\left(1: 1 \mathrm{MeOH} / \mathrm{H}_{2} \mathrm{O}\right)$ of the $80 \%$ pure 4b gave $27 \mathrm{mg}$ (16\% from 22 ) of $\mathbf{4 b}$ as a glassy solid: ${ }^{1} \mathrm{H}$ NMR 7.44-7.31 (m, 5), $7.19(\mathrm{~s}, 1)$, 5.71 (q, 1, $J=6.7), 4.66(\mathrm{~s}, 1), 3.88$ (d, 1, $J=12.0), 3.82$ (d,1, $J=12.0), 1.75$ (br s, 3), 1.64 (d, 3, $J=6.7$ ), 1.50 (s, 3); ${ }^{13} \mathrm{C}$ NMR 166.0, 165.9, 136.7, 134.5, 131.9, 129.5 (2 C), 128.3 (2 C), 127.5, 124.8, 118.6, 116.3, 83.0, 68.9, 48.5, 18.9, 13.5, 13.3; IR (neat) 3244, 1639, 1616, 1404, 1223; HRMS (FAB) calcd for $\mathrm{C}_{19} \mathrm{H}_{24} \mathrm{NO}_{4}\left(\mathrm{MH}^{+}\right) 330.1705$, found 330.1707 .

\section{4-Hydroxy-5-phenyl-3-[2,2,5-trimethyl-4-(1-methylpropenyl)-[1,3]dioxan-5-yl]-1 $\mathrm{H}$-pyri}

din-2-one (28). To a cold solution of diol $4 \mathbf{a}(20 \mathrm{mg}, 0.06 \mathrm{mmol})$ in $2 \mathrm{~mL}$ of 2,2-dimethoxypropane was added $3 \mathrm{mg}$ of TsOH. The mixture was stirred at $25^{\circ} \mathrm{C}$ for $24 \mathrm{~h}$. The solution was diluted with $3 \mathrm{~mL}$ of $\mathrm{CH}_{2} \mathrm{Cl}_{2}$ and washed with saturated $\mathrm{NaHCO}_{3}$ and brine, dried over $\mathrm{Na}_{2} \mathrm{SO}_{4}$ and concentrated under reduced pressure. Flash chromatography on silica 
gel (100:1 $\left.\mathrm{CH}_{2} \mathrm{Cl}_{2} / \mathrm{MeOH}\right)$ gave $7.8 \mathrm{mg}$ of dioxane $\mathbf{2 8}(35 \%)$ as a white solid: $\mathrm{mp} 121-122{ }^{\circ} \mathrm{C}$; ${ }^{1} \mathrm{H}$ NMR $\left(\mathrm{CDCl}_{3}\right)$ 7.46-7.34 (m, 5), 7.15 (s, 1), 5.50 (q, 1, $\left.J=6.7\right), 4.50$ (s, 1), 4.11 (d, 1, $J=$ 12.2), 3.67 (d, $1, J=12.2), 1.61$ (s, 3), $1.60(\mathrm{~d}, 3, J=6.7), 1.54$ (s, 3), 1.52 (s, 3), 1.45 (s, 3); ${ }^{13} \mathrm{C}$ NMR 164.9, 164.7, 134.6, 132.3, 132.2, 129.6 (2 C), 128.4 (2 C), 127.5, 120.7, 116.5, 113.7, 102.3, 75.2, 72.9, 44.7, 29.7, 24.6, 23.2, 14.3, 13.1; IR (neat) 2931, 1617, 1403, 1329, 1219.

\section{4-Hydroxy-5-phenyl-3-[2,2,5-trimethyl-4-(1-methyl-propenyl)-[1,3]dioxan-5-yl]-1 H-pyr}

idin-2-one (30). To a cold solution of diol $4 \mathbf{b}(20 \mathrm{mg}, 0.06 \mathrm{mmol})$ in $2 \mathrm{~mL}$ of 2,2-dimethoxypropane was added $3 \mathrm{mg}$ of TsOH. The mixture was stirred at $25^{\circ} \mathrm{C}$ for $24 \mathrm{~h}$. The solution was diluted with $3 \mathrm{~mL}$ of $\mathrm{CH}_{2} \mathrm{Cl}_{2}$ and washed with saturated $\mathrm{NaHCO}_{3}$ and brine, dried over $\mathrm{Na}_{2} \mathrm{SO}_{4}$ and concentrated under reduced pressure. Flash chromatography on silica gel (100:1 $\left.\mathrm{CH}_{2} \mathrm{Cl}_{2} / \mathrm{MeOH}\right)$ gave $9.3 \mathrm{mg}(42 \%)$ of dioxane 30 as a white solid: $\mathrm{mp} 137-138{ }^{\circ} \mathrm{C}$; ${ }^{1} \mathrm{H}$ NMR 7.39-7.26 (m, 5), 7.09 (s, 1), 5.71 (q, 1, $J=6.7$ ), 4.41 (d, 1, $J=12.2$ ), 4.21 (s, 1,), 3.68 (d, $1, J=12.2), 1.67$ (br s, 3), 1.62 (s, 3), 1.60 (d, 3, $J=6.7), 1.58$ (s, 3), 1.46 (s, 3); ${ }^{13} \mathrm{C}$ NMR 165.3, 163.9, 135.8, 131.6, 130.0, 129.4 (2 C), 128.0 (2 C), 126.9, 122.7, 116.8, 111.1, 101.1, 83.4, 69.6, 41.5, 28.4, 22.3, 19.5, 14.9, 13.5; IR (neat) 2929, 1627, 1427, 1383, 1212.

\section{3-Hydroxymethyl-3-methyl-2-(1-methyl-propenyl)-5-phenyl-3,7-dihydro-2 $\mathrm{H}$-furo[2,3-b} Jpyridin-4-one (2 and 25) and 3-Hydroxymethyl-3-methyl-2-(1-methylpropenyl)-7-phenyl-3,5-dihydro-2H-furo[3,2-c]pyridin-4-one (3 and 26). Keto lactone 22 (123 mg, $0.38 \mathrm{mmol}$ ) was treated with DIBAL/LAH as described above to give $120 \mathrm{mg}$ of crude reduction product after acidic workup. The crude reduction product was dissolved in $5 \mathrm{~mL}$ of $20 \%$ TFA in $\mathrm{CH}_{2} \mathrm{Cl}_{2}$ at $25{ }^{\circ} \mathrm{C}$ under $\mathrm{N}_{2}$. The solution was stirred at $25^{\circ} \mathrm{C}$ for $3 \mathrm{~h}$. The solution was diluted with $10 \mathrm{~mL}$ of $\mathrm{CH}_{2} \mathrm{Cl}_{2}$, washed with saturated $\mathrm{NaHCO}_{3}$ and brine, dried over $\mathrm{Na}_{2} \mathrm{SO}_{4}$, and concentrated under reduced pressure. Flash chromatography of the residue on silica gel (100:1 to $\left.20: 1 \mathrm{CH}_{2} \mathrm{Cl}_{2} / \mathrm{MeOH}\right)$ gave $56.1 \mathrm{mg}$ of a 2.3:1 mixture of CJ169 (2) and the 2-epimer 25, followed by $7.7 \mathrm{mg}$ (7\%) of $\mathbf{2 6}$ as a white solid, and $21.1 \mathrm{mg}(19 \%)$ of CJ16-170 (3) as a white solid. A second column chromatography of the 2.3:1 mixture of $\mathbf{2}$ and $\mathbf{2 5}$ on silica gel $(2: 1$ hexanes/Et $2 \mathrm{O})$ gave $16.9 \mathrm{mg}(15 \%)$ of $\mathrm{CJ}-16169(2)$ as a white solid followed by 
$40.0 \mathrm{mg}(34 \%)$ of the 2 -epimer 25 as a white solid. The total yield of cyclization products is $75 \%$ from 22.

Data for 2 (CJ-16,169): $\quad \operatorname{mp} 212-213{ }^{\circ} \mathrm{C}$ (lit. $\left.{ }^{4} \mathrm{mp} 213-214{ }^{\circ} \mathrm{C}\right) ;{ }^{1} \mathrm{H}$ NMR $\left(\mathrm{CDCl}_{3}\right) 7.81$ (s, 1), 7.53-7.51 (m, 2), 7.42-7.38 (m, 2), 7.34-7.30 (m, 1), 5.57 (q, 1, J=6.7), $4.80(\mathrm{~s}, 1), 3.83(\mathrm{~d}, 1$, $J=10.4), 3.70(\mathrm{~d}, 1, J=10.4), 1.63(\mathrm{~d}, 3, J=6.7), 1.56(\mathrm{~s}, 3), 1.54(\mathrm{~s}, 3) ;{ }^{1} \mathrm{H}$ NMR (acetone- $\left.d_{6}\right)$ $7.78(\mathrm{~s}, 1), 7.50-7.48(\mathrm{~m}, 2), 7.36-7.32(\mathrm{~m}, 2), 7.26-7.22(\mathrm{~m}, 1), 5.59(\mathrm{q}, 1, J=6.7), 4.80(\mathrm{~s}, 1)$, $3.74(\mathrm{~d}, 1, J=9.8), 3.70(\mathrm{~d}, 1, J=9.8), 1.59(\mathrm{~d}, 3, J=6.7), 1.50(\mathrm{~s}, 3), 1.46(\mathrm{~s}, 3) ;{ }^{13} \mathrm{C} \mathrm{NMR}$ $\left(\mathrm{CDCl}_{3}\right)$ 135.1, 131.7, 129.3 (2 C), 128.2 (2 C), 127.1, 124.5, 110.5, 94.7, 66.4, 49.1, 24.8, 13.0, 12.9, four carbons were not observed; ${ }^{13} \mathrm{C}$ NMR (acetone- $d_{6}$ ) 165.5, 149.7 (br), 137.3, 133.7, 130.5 (2 C), 129.3 (2 C), 127.9, 125.3, 111.8 (br), 95.2 (br), 67.2, 50.4, 25.7, 13.5, 13.4, two carbons were not observed; IR (neat) 3051, 1598, 1418, 1299, 1235, 1199, 1076; UV (MeOH) 204 (25,000), 231 (18,000); HRMS (CI) calcd for $\mathrm{C}_{19} \mathrm{H}_{22} \mathrm{NO}_{3}\left(\mathrm{MH}^{+}\right)$312.1599, found 312.1587. The spectral data match those reported for synthetic and natural CJ-16,169. ${ }^{2,4}$

Data of 3 (CJ-16,170): $\quad \operatorname{mp~} 195-196{ }^{\circ} \mathrm{C} ;{ }^{1} \mathrm{H}$ NMR $\left(\mathrm{CDCl}_{3}\right)$ 7.55-53 (m, 2), $7.48(\mathrm{~s}, 1)$, 7.43-7.40 (m, 2), 7.35-7.31 (m, 1), $5.78(\mathrm{~d}, 1, J=9.8), 5.63(\mathrm{q}, 1, J=6.7), 4.73(\mathrm{~s}, 1), 3.89(\mathrm{~d}, 1$, $J=10.4), 3.69(\mathrm{dd}, 1, J=10.4,9.8), 1.74(\mathrm{~s}, 3), 1.71(\mathrm{~d}, 3, J=6.7), 1.30(\mathrm{~s}, 3) ;{ }^{1} \mathrm{H}$ NMR (acetone- $\left.d_{6}\right)$ 7.58-7.56 (m, 2), $7.57(\mathrm{~s}, 1), 7.38-7.34(\mathrm{~m}, 2), 7.28-7.24(\mathrm{~m}, 1), 5.60(\mathrm{q}, 1, J=6.7)$, $5.37(\mathrm{~d}, 1, J=9.8), 4.86(\mathrm{~s}, 1), 3.68(\mathrm{~d}, 1, J=10.4), 3.60(\mathrm{dd}, 1, J=10.4,9.8), 1.68(\mathrm{~s}, 3), 1.65$ $(\mathrm{d}, 3, J=6.7), 1.17(\mathrm{~s}, 3) ;{ }^{13} \mathrm{C}$ NMR $\left(\mathrm{CDCl}_{3}\right) 166.1,163.3,134.2,132.5,130.5,128.7(2 \mathrm{C})$, 127.7, 127.6 (2 C), 123.7, 117.1, 112.0, 94.4, 70.1, 50.7, 16.9, 13.9, 13.1; IR (neat) 2926, 1649, $1614,1446,1217,1057,785,696 ;{ }^{13} \mathrm{C}$ NMR (acetone- $\left.d_{6}\right)$ 166.6, 163.0, 135.7, 134.7, 133.0, 129.8 (2 C), 128.9 (2 C), 124.3, 117.2, 111.5, 95.1, 70.3, 52.0, 17.5, 14.4, 13.6; IR (neat) 2926, 1649, 1614, 1446, 1217, 1057, 785, 696; UV (MeOH) 204 (22,900), 246 (21,300); HRMS (CI) calcd for $\mathrm{C}_{19} \mathrm{H}_{22} \mathrm{NO}_{3}\left(\mathrm{MH}^{+}\right)$312.1599, found 312.1592. The spectral data match those reported for natural CJ-16,170. ${ }^{2}$

Data for 25: $\operatorname{mp~212-213~}{ }^{\circ} \mathrm{C} ;{ }^{1} \mathrm{H}$ NMR $\left(\mathrm{CDCl}_{3}\right) 7.74(\mathrm{~s}, 1), 7.50-48(\mathrm{~m}, 2), 7.41-7.37(\mathrm{~m}$, 2), 7.33-7.29 (m, 1), $5.63(\mathrm{q}, 1, J=6.7), 4.60(\mathrm{~s}, 1), 3.90(\mathrm{~d}, 1, J=9.8), 3.86(\mathrm{~d}, 1, J=9.8), 1.70$ 
(s, 3), 1.69 (d, 3, $J=6.7), 1.24$ (s, 3); ${ }^{1} \mathrm{H}$ NMR (acetone- $d_{6}$ ) 7.76 (s, 1), 7.49-7.47 (m, 2), 7.36-7.32 (m, 2), 7.27-7.23 (m, 1), 5.66 (q, 1, $J=6.7), 4.66$ (s, 1), 3.94 (d, 1, $J=9.8), 3.87$ (d, 1, $J=9.8), 1.70$ (s, 3), 1.66 (d, 3, $J=6.7), 1.18$ (s, 3); ${ }^{13} \mathrm{C} \mathrm{NMR}\left(\mathrm{CDCl}_{3}\right) 135.1,130.5,129.2$ (2 C), 128.2 (2 C), 127.2, 123.7, 111.8, 91.1, 68.8, 50.9, 17.6, 13.1, 13.0, four carbons were not observed; IR (neat) 3050, 1599, 1416, 1299, 1253, 1083; UV (MeOH) 206 (25,300), 232 $(18,100)$; HRMS (CI) calcd for $\mathrm{C}_{19} \mathrm{H}_{22} \mathrm{NO}_{3}\left(\mathrm{MH}^{+}\right) 312.1599$, found 312.1609.

Data for 26: $\mathrm{mp} 194-195{ }^{\circ} \mathrm{C}\left(\right.$ lit. $\left.^{3} \mathrm{mp} 194-195{ }^{\circ} \mathrm{C}\right) ;{ }^{1} \mathrm{H}$ NMR $\left(\mathrm{CDCl}_{3}\right) 7.55-453$ (m, 2), 7.50 (s, 1), 7.44-7.40 (m, 2), 7.36-7.32 (m, 1), 5.87 (d, 1, $J=11.0, \mathrm{OH}), 5.57$ (q, 1, $J=6.7), 4.96$ (s, 1), 3.84 (d, 1, $J=11.4$ ), 3.49 (dd, 1, $J=11.4,11.0), 1.66$ (d, 3, $J=6.7$ ), 1.59 (s, 3), 1.57 (s, 3); ${ }^{1} \mathrm{H}$ NMR (acetone- $d_{6}$ ) 7.71-7.58 (m, 2), 7.56 (s, 1), 7.38-7.34 (m, 2), 7.29-7.25 (m, 1), 5.58 (q, 1, $J=6.7$ ), 5.70 (br s, 1), 4.95 (s, 1), 3.65 (d, $1, J=10.4$ ), 3.30 (d, 1, $J=10.4$ ), 1.59 (d, 3, $J=6.7$ ), 1.55 (s, 3), 1.42 (s, 3); ${ }^{13} \mathrm{C}$ NMR $\left(\mathrm{CDCl}_{3}\right)$ 166.9, 163.0, 134.3, 132.4, 131.1, 128.8 (2 C), 127.8, 127.6 (2 C), 125.1, 116.8, 112.0, 99.5, 66.3, 49.3, 24.4, 13.1 (2 C); IR (neat) 2926, 2861, 1649, 1614, 1598, 1430; UV (MeOH) 204 (22,700), 246 (20,400); HRMS (CI) calcd for $\mathrm{C}_{19} \mathrm{H}_{22} \mathrm{NO}_{3}$ $\left(\mathrm{MH}^{+}\right)$312.1599, found 312.1603. The spectral data are identical to those reported by Clive. ${ }^{3}$

Cyclization of 4 in $4: 1$ water/TFA. Keto lactone $22(62 \mathrm{mg}, 0.19 \mathrm{mmol})$ was treated with DIBAL/LAH as described above to give $60 \mathrm{mg}$ of crude reduction product after acidic workup. The crude reduction product was dissolved in $3 \mathrm{~mL}$ of $20 \%$ TFA in water at $25^{\circ} \mathrm{C}$ under $\mathrm{N}_{2}$. The solution was stirred at $25^{\circ} \mathrm{C}$ for $12 \mathrm{~h}$. The reaction mixture was extracted with $\mathrm{CH}_{2} \mathrm{Cl}_{2}$. The extracts were washed with saturated $\mathrm{NaHCO}_{3}$ and brine, dried over $\mathrm{Na}_{2} \mathrm{SO}_{4}$, and concentrated under reduced pressure. Flash chromatography of the residue on silica gel (100:1 to $20: 1 \mathrm{CH}_{2} \mathrm{Cl}_{2} / \mathrm{MeOH}$ ) gave $31.2 \mathrm{mg}$ of a $4: 5$ mixture of 2 and 25 , followed by $4.7 \mathrm{mg}(8 \%)$ of $\mathbf{2 6}$, and $7.3 \mathrm{mg}(13 \%)$ of $\mathbf{3}$. A second column chromatography of the $4: 5$ mixture of $\mathbf{2}$ and $\mathbf{2 5}$ on silica gel (2:1 hexanes/ $\left.\mathrm{Et}_{2} \mathrm{O}\right)$ gave $13.5 \mathrm{mg}(24 \%)$ of $\mathbf{2}$ followed by $17.7 \mathrm{mg}(30 \%)$ of $\mathbf{2 5}$. The total yield for cyclization products from $\mathbf{2 2}$ is $75 \%$.

2-(4-Hydroxy-2-oxo-5-phenyl-1,2-dihydropyridin-3-yl)-propyl trifluoroacetate (31) and 3-Methyl-7-phenyl-3,5-dihydro-2H-furo[3,2-c]pyridin-4-one (32). Alcohol 24 (44 mg, 0.18 
mmol) was dissolved in $2 \mathrm{~mL}$ of $20 \% \mathrm{TFA}$ in $\mathrm{CH}_{2} \mathrm{Cl}_{2}$ under $\mathrm{N}_{2}$. The solution was stirred at $25{ }^{\circ} \mathrm{C}$ for $24 \mathrm{~h}$. The solution was diluted with $5 \mathrm{~mL}$ of $\mathrm{CH}_{2} \mathrm{Cl}_{2}$, washed with brine, dried over $\mathrm{Na}_{2} \mathrm{SO}_{4}$ and concentrated under reduced pressure. The ${ }^{1} \mathrm{H}$ NMR spectrum showed that the alcohol was totally converted to trifluoroacetate 31 , which could not be purified chromatographically due to its hydrolysis to regenerate $\mathbf{2 4}$.

Data for 31: ${ }^{1} \mathrm{H}$ NMR 7.61-7.57 (m, 3), 7.55 (s, 1), 7.36-7.26 (m, 2), 4.73 (dd, 1, $J=10.3$, 8.6), 4.66 (dd, $1, J=10.3,6.7$ ), 3.87-3.79 (m, 1), 1.41 (d, 3, $J=7.0)$; IR (neat), 1785, 1670, $1165,1437$.

Trifluoroacetate 31 was dissolved in $1 \mathrm{~mL}$ of DMF and treated with $40 \mathrm{mg}$ of KI under $\mathrm{N}_{2}$. The mixture was heated at $70{ }^{\circ} \mathrm{C}$ for $3 \mathrm{~h}$. After cooling to $25^{\circ} \mathrm{C}$, the solution was diluted with $10 \mathrm{~mL}$ of $\mathrm{CH}_{2} \mathrm{Cl}_{2}$, washed with saturated $\mathrm{NaHCO}_{3}$ and brine, dried over $\mathrm{Na}_{2} \mathrm{SO}_{4}$, and concentrated under reduced pressure. Flash chromatography of the residue on silica gel (50:1 $\left.\mathrm{CH}_{2} \mathrm{Cl}_{2} / \mathrm{MeOH}\right)$ gave $38 \mathrm{mg}$ of cyclization product 32 (88\% from 24) as a white solid: $\mathrm{mp}$ 213-214 ${ }^{\circ} \mathrm{C} ;{ }^{1} \mathrm{H}$ NMR 7.56-7.52 (m, 2), 7.50 (s, 1), 7.44-7.38 (m, 2), 7.35-7.29 (m, 1), 4.80 (dd, $1, J=9.2,9.2), 4.32$ (dd, $1, J=9.2,5.5), 3.70-3.59$ (m, 1), 1.43 (d, $3, J=7.0) ;{ }^{13} \mathrm{C}$ NMR 166.9, 163.2, 134.2, 133.1, 128.6 (2 C), 127.5 (2 C), 127.4, 114.0, 111.0, 80.2, 34.4, 18.7; IR (neat), 2961, 1651, 1599, 1433, 1202; UV (MeOH) 205 (18,200), 244 (19,300); HRMS (CI) calcd for $\mathrm{C}_{14} \mathrm{H}_{13} \mathrm{NO}_{2}\left(\mathrm{MH}^{+}\right)$227.0946, found 227.0943.

Cladobotryal or CJ-15,196 (1). To a solution of $2(12.4 \mathrm{mg}, 0.04 \mathrm{mmol})$ in $0.5 \mathrm{~mL}$ of $\mathrm{CH}_{2} \mathrm{Cl}_{2}$ was added Dess-Martin periodinane $(19.1 \mathrm{mg}, 0.045 \mathrm{mmol})$ at $0{ }^{\circ} \mathrm{C}$. After stirring at $25^{\circ} \mathrm{C}$ for $30 \mathrm{~min}$, the reaction mixture was diluted with $5 \mathrm{~mL}$ of $\mathrm{CH}_{2} \mathrm{Cl}_{2}$ and washed with $1 \mathrm{~mL}$ of saturated aqueous $\mathrm{NaHCO}_{3}$ and $1 \mathrm{~mL}$ of $20 \% \mathrm{Na}_{2} \mathrm{~S}_{2} \mathrm{O}_{3}$. The organic phase was then washed with aqueous $\mathrm{NaHCO}_{3}$ and brine, dried over $\mathrm{Na}_{2} \mathrm{SO}_{4}$, and concentrated under reduced pressure. Flash chromatography on silica gel (2:1 hexanes/EtOAc) gave $11.7 \mathrm{mg}(95 \%)$ of cladobotryal (1) as a white solid: $\operatorname{mp~95-96~}{ }^{\circ} \mathrm{C}\left(1 \mathrm{lit} .{ }^{4} \mathrm{mp} 95-97{ }^{\circ} \mathrm{C}\right) ;{ }^{1} \mathrm{H} \mathrm{NMR}\left(\mathrm{CDCl}_{3}\right) 9.66(\mathrm{~s}, 1), 7.98(\mathrm{~s}, 1)$, 7.48-7.39 (m, 5), 5.88 (q, 1, $J=6.7$ ), 4.98 (s, 1), 1.70 (d, 3, $J=6.7$ ), 1.63 (s, 3), 1.54 (br s, 3); ${ }^{1} \mathrm{H}$ NMR (Acetone- $\left.d_{6}\right) 9.57$ (s, 1), 7.74 (s, 1), 7.43-7.41 (m, 2), 7.38-7.35 (m, 2), 7.31-7.27 (m, 1), 
$5.78(\mathrm{q}, 1, J=6.7), 4.97(\mathrm{~s}, 1), 1.60(\mathrm{~d}, 3, J=6.7), 1.59(\mathrm{~s}, 3), 1.53(\mathrm{~s}, 3) ;{ }^{13} \mathrm{C} \mathrm{NMR}\left(\mathrm{CDCl}_{3}\right)$ 203.4, 168.1, 158.2, 149.8, 133.8, 130.6, 129.3 (2 C), 128.9 (2 C), 127.9, 126.4, 121.4, 105.4, 93.4, 57.9, 22.1, 13.2, 12.1; ${ }^{13} \mathrm{C}$ NMR (Acetone- $d_{6}$ ) 201.2, 131.8, 130.8 (2 C), 129.9 (2 C), 128.7, 125.5, 107.8, 59.1, 20.6, 13.5 (2 C); IR (neat) 2920, 1727, 1648, 1596, 1443; UV (MeOH) 208 (24,000), $236(19,000)$; HRMS calcd for $\mathrm{C}_{19} \mathrm{H}_{20} \mathrm{NO}_{3}\left(\mathrm{MH}^{+}\right) 310.1443$, found 310.1435. The spectral data match those reported for synthetic and natural CJ-15196. ${ }^{1,2,4}$

The ${ }^{1} \mathrm{H}$ NMR spectrum of $\mathbf{1}$ is $\mathrm{pH}$ dependent, with most protons shifted downfield in the presence of acid: ${ }^{1} \mathrm{H}$ NMR $\left(\mathrm{CDCl}_{3}+1 \%\right.$ TFA) 9.63 (s, 1), 8.05 (s, 1), 7.50-7.37 (m, 5), 6.00 (q, $1, J=6.7), 5.32$ (s, 1), 1.76 (d, 3, $J=6.7), 1.72$ (s, 3), 1.53 (br s, 3). 
Table 2. Comparison of ${ }^{1} \mathrm{H}$ and ${ }^{13} \mathrm{C}$ NMR data of 14a, 14b, 14c and 14d.

\begin{tabular}{llll}
\hline${ }^{1} \mathrm{H} \mathrm{NMR}\left(\mathrm{CDCl}_{3}\right)$ & & $\mathbf{2 6}$ & \\
$\mathbf{2}$ & $\mathbf{2 5}$ & $7.55-453(\mathrm{~m}, 2)$ & $\mathbf{3}$ \\
$7.81(\mathrm{~s}, 1)$ & $7.74(\mathrm{~s}, 1)$ & $7.50(\mathrm{~s}, 1)$ & $7.55-7.53(\mathrm{~m}, 2)$, \\
$7.53-7.51(\mathrm{~m}, 2)$ & $7.50-48(\mathrm{~m}, 2)$ & $\mathrm{s}, 1)$ \\
$7.42-7.38(\mathrm{~m}, 2)$ & $7.41-7.37(\mathrm{~m}, 2)$ & $7.44-7.40(\mathrm{~m}, 2)$ & $7.43-7.40(\mathrm{~m}, 2)$ \\
$7.34-7.30(\mathrm{~m}, 1)$ & $7.33-7.29(\mathrm{~m}, 1)$ & $7.36-7.32(\mathrm{~m}, 1)$ & $7.35-7.31(\mathrm{~m}, 1)$ \\
--- & --- & $5.87(\mathrm{~d}, 1, \mathrm{~J}=11.0)$ & $5.78(\mathrm{~d}, 1, \mathrm{~J}=9.8)$ \\
$5.57(\mathrm{q}, 1, \mathrm{~J}=6.7)$ & $5.63(\mathrm{q}, 1, \mathrm{~J}=6.7)$ & $5.57(\mathrm{q}, 1, \mathrm{~J}=6.7)$ & $5.63(\mathrm{q}, 1, \mathrm{~J}=6.7)$ \\
$4.80(\mathrm{~s}, 1)$ & $4.60(\mathrm{~s}, 1)$ & $4.96(\mathrm{~s}, 1)$ & $4.73(\mathrm{~s}, 1)$ \\
$3.83(\mathrm{~d}, 1, \mathrm{~J}=10.4)$ & $3.90(\mathrm{~d}, 1, \mathrm{~J}=9.8)$ & $3.84(\mathrm{~d}, 1, \mathrm{~J}=11.4)$ & $3.89(\mathrm{~d}, 1, \mathrm{~J}=10.4)$ \\
$3.70(\mathrm{~d}, 1, \mathrm{~J}=10.4)$ & $3.86(\mathrm{~d}, 1, \mathrm{~J}=9.8)$ & $3.49(\mathrm{dd}, 1, \mathrm{~J}=11.4,11.0)$ & $3.69(\mathrm{dd}, 1, \mathrm{~J}=10.4,9.8)$ \\
$1.63(\mathrm{~d}, 3, \mathrm{~J}=6.7)$ & $1.70(\mathrm{~s}, 3)$ & $1.66(\mathrm{~d}, 3, \mathrm{~J}=6.7)$ & $1.74(\mathrm{~s}, 3)$ \\
$1.56(\mathrm{~s}, 3)$ & $1.69(\mathrm{~d}, 3, \mathrm{~J}=6.7)$ & $1.59(\mathrm{~s}, 3)$ & $1.71(\mathrm{~d}, 3, \mathrm{~J}=6.7)$ \\
$1.54(\mathrm{~s}, 3)$ & $1.24(\mathrm{~s}, 3)$ & $1.57(\mathrm{~s}, 3)$ & $1.30(\mathrm{~s}, 3)$ \\
& & & \\
${ }^{13} \mathrm{C} \mathrm{NMR}\left(\mathrm{CDCl}_{3}\right)$ & & & \\
$\mathbf{2}$ & $\mathbf{2 5}$ & $\mathbf{2 6}$ & $\mathbf{3}$ \\
--- & --- & 166.9 & 166.1 \\
--- & --- & 163.0 & 163.3 \\
135.1 & 135.1 & 134.3 & 134.2 \\
131.7 & 130.5 & 132.4 & 132.5 \\
--- & --- & 131.1 & 130.5 \\
$129.3(2 \mathrm{C})$ & $129.2(2 \mathrm{C})$ & $128.8(2 \mathrm{C})$ & $128.7(2 \mathrm{C})$ \\
$128.2(2 \mathrm{C})$ & $128.2(2 \mathrm{C})$ & 127.8 & 127.7 \\
127.1 & 127.2 & $127.6(2 \mathrm{C})$ & $127.6(2 \mathrm{C})$ \\
124.5 & 123.7 & 125.1 & 117.1 \\
--- & --- & 116.8 & 13.1 \\
110.5 & 111.8 & 112.0 & 16.9 \\
94.7 & 91.1 & 99.5 & 50.7 \\
66.4 & 68.8 & 66.3 & 13.9 \\
49.1 & 50.9 & 24.4 & \\
24.8 & 17.6 & 13.1 & \\
13.0 & 13.0 & & \\
12.9 & & & \\
\hline
\end{tabular}

-OH signal at 5.87 for $\mathbf{2 6 c}$ and 5.78 for $\mathbf{3}$ disappeared on addition of $\mathrm{D}_{2} \mathrm{O}$. 